\title{
SYNTHESIZABLE AND PROTOTYPIC VISUAL-TACTILE SYSTEM-IN FPGA: AN ALTERNATIVE TO ANALYSIS AND IMPROVEMENT OF THE VOICE QUALITY FOR THE HEARING IMPAIRED PEOPLE
}

\author{
R. L. ALVES ${ }^{1 *}$, A. M. J. SOARES ${ }^{1}$, R. C. S. FREIRE ${ }^{2}$ and C. M. G. S. LIMA ${ }^{3}$ \\ ${ }^{1}$ Instituto Federal de Educação, Ciência e Tecnologia do Rio Grande do Norte \\ ${ }^{2}$ Universidade Federal de Campina Grande \\ ${ }^{3}$ Universidade do Minho - Portugal \\ rodrigo.leone@ifrn.edu.br*
}

Artigo submetido em fevereiro/2016 e aceito em fevereiro/2016

DOI: $10.15628 /$ holos.2016.4086

\begin{abstract}
Oral communication comprises one of the most important forms of social interaction. The process of learning the spoken language depends on the hearing, therefore, the total or partial loss of hearing sensitivity hinders such aspect. Digital signal processing techniques with non-invasive character are used for diagnosis, support and improvement of the voice quality of the deaf. Thus, the present study aims to propose and develop a system of analysis and correction of vocal disorders by means of visual and tactile feedback with module implemented in programmable device type FPGA (Field Programmable Gate Array). The results point to the
\end{abstract}

potential of a proposed intervention as a helper for sensory substitution, being based on the monitoring and control of speech, in order to allow for the assessment and remediation by means of an electronic resource, allowing deaf individuals to obtain a support for learning the spoken language. The possibilities for improvements in communication skills observed in this study are dependent on the capability of the device together with the speech therapist, integrating therapies with the support of the family, the time and the motivation of the user, factors that cooperate for the success of this approach.

KEYWORDS: Deafness, Speech, FPGA, Assistive Technology and Visual-Tactile Stimulation.

\section{SISTEMA VÍSUO-TÁTIL SINTETIZÁVEL E PROTOTIPÁVEL EM FPGA: UMA ALTERNATIVA PARA ANÁLISE E MELHORIA DA QUALIDADE DA VOZ DE DEFICIENTES AUDITIVOS}

A comunicação oral compreende uma das mais importantes formas de interação social. O processo de aprendizado da linguagem falada depende da audição, logo, a perda total ou parcial da sensibilidade auditiva dificulta tal aspecto. Técnicas de Processamento Digital de Sinais com caráter não-invasivo são usadas para diagnóstico, apoio e melhoria da qualidade da voz dos surdos. Desse modo, o presente estudo tem como objetivo propor e desenvolver um sistema de análise e correção de desordens vocais por meio da realimentação visual e tátil com módulo implementado em um dispositivo programável do tipo FPGA (Field Programmable Gate Array). Os resultados apontam para o potencial de uma proposta de intervenção como medida auxiliar para substituição sensorial, sendo baseada no monitoramento e controle da fala, de modo a permitir a avaliação e remediação por meio de um recurso eletrônico, possibilitando que os indivíduos surdos obtenham um suporte a mais para aprendizado da língua oral. As possibilidades de melhorias nas habilidades comunicativas observadas neste estudo dependem da potencialidade do dispositivo em conjunto com a atuação do fonoaudiólogo, a integração das terapias com o apoio da família, o tempo de utilização e a motivação do usuário, fatores estes que colaboram para o sucesso desta abordagem.

KEYWORDS: Deafness, speech, Assistive technology, FPGA and Tactile-visual stimulation. 


\section{INTRODUCTION}

The hearing plays an essential role in human communicative process, considering that the integrity of such sense gives to the individual the ability to hear, understand and play properly sounds from the environment in which one lives, as well as being a perception mechanism of the world. In this context, the communicative function is compromised by total or partial loss of hearing sensitivity, inserting the deaf individuals in a context marked by socio-educational, emotional consequences and related to cognition, for this reason this theme contains a social call, requiring methodologies and mediator resources for the betterment of the perceptual processes, language acquisition through the sensory substitution and in social interactions (ALVES, SOARES \& OLIVEIRA, 2014).

A necessary and accurate communicative function requires the performance of mechanisms linked to speech, but the hearing loss, from the lightest to the most severe level, inhibits the development of language and speech, and thus entail losses of various proportions, such as educational and psychosocial, impacting negatively on the affective and social relations of the hearing impaired person (SPERI, 2013), facts like these strengthen the proposition that the effects related to lack of auditory stimulation on the development of oral language and speech intelligibility are in fact harmful (OLIVEIRA, PENNA and LEMOS, 2015).

For many years, scholars have focused their efforts for the implementation of proposals for inclusive education. Thereby, unfounded arguments stand out that hearing impaired person who does not develop speech lose more and more space, because although consists of a complex and time-consuming process, currently has many clinical methods and electronic equipment that support hearing in order to they develop the speech. Thus, many significant changes can be found in the history of deaf education, focusing mainly on the speech and auditory-verbal approaches, which according to BEVILACQUA et al. (2011) and LUCCHESI et al. (2015), aim to assist individuals with hearing loss to use their residual hearing to learn listening and speaking, i.e. methods that advocate the education for the deaf must be based on oral communication.

In recent decades, the technological capabilities are allowing better performances on the quality of interventions and sensory substitution, which shows it as an important initiative to maximize the inclusion of people with hearing loss $(\mathrm{HL})$, then increasing the possibility of creating new devices that can "assist in the speech of the hearing impaired, that is, in the teaching of spoken communication as well as on its insertion in the social and educational context" (ALVES, SOARES \& OLIVEIRA, 2014, p. 2).

The voice of people with auditory processing disorder needs analysis and rehabilitation actions to be improved, besides therapies and/or equipment to support the process of speech. At first, the only strategy used by professionals in the field was limited to clinical, auditory-perceptual, and physiological evaluations, which according to MARTINS, COUTO and GAMA (2015), and VALADEZ et al. (2012), are invasive character techniques and often cause nuisance and malaise on the patient. However, technological advances have enabled the emergence of computational mechanisms allied to procedures, and, therefore, non-invasive, i.e. the method of acoustic analysis, which makes possible to examine the vocal parameters, its quality and its operation through the use of voice signal samples, without necessarily being a costly and invasive practice, 
assisting in the therapeutic process, in addition to efficiently identify changes in sound production and its classification (COSTA et al., 2007 and VIEIRA, 2014).

Despite advances in rehabilitation therapies and in assistive technologies, the spoken language learning is not a quick and easy task to be carried out by the deaf person, not to mention that requires the successive use of other senses to compensate the hearing loss. In this perspective of sensory substitution, the visual feedback features great potential in the pedagogical field (ANDREIS-WITKOSKI \& FILIETAZ, 2014).

With respect to the use of touch for learning speech, it can be said that this shows promising results, although lower than the ear canal. Thus, it becomes commonly natural that hearing impaired will join the tact and/or vision for the transmission of acoustic information, being feasible, therefore, the integration of both ways alternately (BARBACENA, 2010), as well as in the proposed innovation of new technological components based on integrative strategy of vision and touch, i.e. visual-tactile.

Most of the time, the technological artifacts and resources available for technical assistance present high prices because there is not always national production for such a purpose, so importing raises costs for the end user, making the product inaccessible. In this context, the availability of new, robust and cheaper electronic components boosts their employment in resource utilization of accessibility and assistive technology. With regard to the creation of systems for recognition of vocal characteristics, it should be noted that such projects require the attendance of certain restrictions in real time to better performance, smaller area, greater processing power, storage and lower power consumption, whose requirements easily met with the use of computing embedded systems (LIMA et al., 2015).

For the reason above and knowing that the acoustic analysis is based on the digital signal processing (SANTOS, 2015), it is believed that there are many fronts where electrical engineering can act, since many modern electronic devices are capable of synthesizing vocal analysis systems with emphasis on extraction of significant signal characteristics and its subsequent treatment. Thus, we highlight that a relevant possibility is on reconfigurable computing, because with the advances seen in electronic devices known as FPGAs ${ }^{1}$ (Field Programmable Gate Array), both in reducing costs and increasing the programming capacity and flexibility, it is considered that these are an excellent alternative to implementation of digital signal processing techniques.

There is still a wide research field in such area, however, this study represents an attempt within the correction and control of fundamental frequency using smaller electronic and programmable components. The cooperative use of modern devices and analytical vocal techniques show up as a beneficial factor because of the equipment potential in emphasis, moreover, the same supplies storage-capacity requirements, making room for new paradigms and perspectives for professionals involved in digital signal processing and voice acoustic analysis.

Regarding the encoding of the extracted parameter in vibrotactile stimulations, this task was based on the algorithm creation with improvement of the techniques proposed by BARBACENA (2010) and BARROS (2004), which investigated the voice information transmission by tactile stimuli, and that such techniques were adapted in this study for proper use in reconfigurable

\footnotetext{
${ }^{1}$ FPGA (Field Programmable Gate Array) consists of a set of integrated circuits connected by an array of programmable logic cells, i.e. are integrated circuits that have logical blocks and programmable interconnects.
} 
computing, since these have been configured in programmable device with hardware description language of very high speed, that is, consisted of a processing algorithm similar to those developed by such authors, but with the advantage of a language chosen because of its multiple levels of abstraction, broadening the scope of applications of this language and a more portable model of electronic systems for implementation in hardware consisting of thousands of logic cells. In addition, unlike other studies cited, a single integrated reprogrammable circuit of FPGA-type introduces the ability to perform basically the same done by several traditional integrated circuits.

Starting from the assumption that there is a lack of new approaches that make possible the cost/performance relation analysis and correction of vocal parameters of the HL bearer, allowing the same to carry out a monitoring of your own speech and, consequently, the acquisition of oral language, this study aims to investigate and develop an analysis and voice improvement system for deaf people. To this end, the device explores as alternative method the visual-tactile stimulation, being implemented in a FPGA-type electronic component, with the priority aim to supply restrictions as real-time performance, cost/benefit, processing and storage capacity, and even power consumption.

The parameter measured and evaluated in experimental procedures, described later, was the fundamental frequency through an algorithm that performs the task of estimating the perceptually equivalent pitch. In this context, so that the information could be passed to the user, the configuration methodology of proposed architecture consisted basically in the acquisition of voice signal and its processing. The necessary techniques for extraction of the desired feature, its classification compared to normal patterns, as well as the return of the extracted parameters were performed. Thereby, the user views in an display the measured value of your $F_{0}$ and feels through vibrations, larger or smaller depending on the emitted voice, if this value is moving close or away from expected values, and may then try to increase or decrease the pitch to hit the target, namely the default value for its fundamental frequency. The tactile actuator is placed in one of the fingertips of the user.

The project has a few buttons and keys for the user to enter the time you want to start a new signal capture, show the results and start stimuli, clear the memory that stores the processed data, as well as the levels of training, because variables stored for the test patterns differ between male, female and children, which requires the indication of one of these three classifications by the user. In this research, the device used was a FPGA from family Cyclone IV that due to the diffusion of computer and electronic systems more robust and flexible, stands out due to factors such as increased density logic, memories, multipliers, storage capacity and flexibility, plus the programming possibilities offered by hardware description language used, named VHDL (Very High Speed Integrated Circuits Hardware Description Language) provide promising prospects and are suitable for the implementation in the area of digital signal processing by linear and non-linear methods of speech production, due to its excellent performance and versatility, introducing in the field of academic research an equipment that can subsequently result in a more robust prototype applied in mobile cellular systems.

\section{VOCAL QUALITY OF THE HEARING IMPAIRED}

The communicative intention of the hearing impaired is influenced by the context in which it is inserted, as a result, the vocal characteristics of that group present remarkable peculiarities 
(ALVES, SOARES \& OLIVEIRA, 2014). Thus, the voice passes through several transformations in the course of life, being aurally noticeable (ALMEIDA et al., 2015), bearing in mind that it is a parameter directly related to the age and sex of the speaker (ANDRADE et al., 2015). Moreover, even with a basic pattern of normality that identifies the voice quality, it should be noted that the talks generally consists of an aspect which toggles through circumstances of human beings, i.e. still depends on physical or psychological conditions (CIELO et al., 2015).

As a result of this type of sensory impairment, the deaf speech presents many changes in all genres and age group. The parameters with more changes to mention are: resonance, fundamental frequency - $F_{0}$, intensity, vocal quality, intelligibility, speed and rhythm, articulation and breathing.

The hearing of the human being controls his speech because the individual can through it monitor the duration, timbre, intensity and the tone of your voice, for this reason it is a crucial component to the teaching/learning process of speech (OLIVEIRA, PENNA, and LEMOS, 2015).

In this sense, LUCCHESI et al. (2015) state that the hearing impaired presents considerable difficulty to manage air flow and expel air before concluding the speech, fact that compromises integrity and vocal quality, changing the speed, rhythm, intonation, as well as disruption of the respiratory pattern.

In the case of vocal production, the fundamental frequency relates to an important feature and that deserves special attention, being related to gender and age. KREMER \& GOMES (2014) conceptualize fundamental frequency of the voice as being the number of vibrating cycles per second of vocal folds, and its perceptual form is called pitch.

In comparison, regarding the limitations from little hearing perception, the frequency of sounds produced by deaf children is quite high compared to those produced by listener children since the first years of life (MARTINS et al., 2012).

According to CHRISTMANN et al. (2015), in the neonatal period the fundamental frequency is presented with high intensity and glottal attack relatively hard. An improvement on the modulation with reduced glottal attack occurs in early childhood, but the biggest changes in voice happens in the adolescence, becoming stable in adulthood, and change again later, with aging.

There is no standardization in the values of fundamental frequency of the voice in all the studies, bearing in mind that researchers use distinct approaches, nevertheless with small differences. According to SOUZA (2012) and SANTOS (2015), in children, the values of the referred parameter are independent of sex, being approximately equal to $300 \mathrm{~Hz}$. For adult men, the values of normality are in the range from $80 \mathrm{~Hz}$ to $150 \mathrm{~Hz}$, and in adult women reach $150 \mathrm{~Hz}$ to $250 \mathrm{~Hz}$. In deaf people, the value of $F_{0}$ is higher than $350 \mathrm{~Hz}$, in both sexes.

Basically, any changes in the auditory system will take place in the absence of the subject's ability to carry out the control of speech, undermining the intelligibility and fundamental frequency. However, through studies and systematic procedures can correct and remedy the aspect in question. It is worth mentioning that there are still available for speech therapy professionals some auxiliary hearing and electronic resources that can be used by people with hearing impairments, such as personal sound amplification products (PSAPs), the surgical procedure of cochlear implant $(\mathrm{Cl})$ and frequency modulation (FM) that eliminates interference of sounds from the environment, but the results of this kind of strategy will be more promising when 
started early, and people who already live with the loss hearing for longer and with more severe level do not benefit from relatively easily and praiseworthy of such equipment because when hearing loss is diagnosed in childhood "speech therapy intervention is quite promising for the development of hearing and oral communication" (SPERI, 2013, p. 63).

In a broad sense, it can be said that the system proposed in this research differs from the above mechanisms considering that it does not emphasize the development of residual hearing, but a support with focus on sensory substitution allied to oral therapies, not in order to amplify the sound received by the disabled, but to make the correct changes in individual voice realizing the difference of the vibrations of a tactile actuator, placed on the end of one of his fingers. Undeniably, the reduction of deafness-related effects requires the intervention in more and more younger children, but for the proposed correction of problematic characteristics of speech of the $\mathrm{HL}$ bearer be established with appropriate results, it is important that such intervention makes it possible, although with greater difficulty, the access to the spoken language not only during initial periods of language acquisition, counting with most advanced technologies as regards not only the improvement in receptive language, but especially in expressive, including improved vocal quality (COELHO et al., 2009), which justifies the viability of scaled-projects as explained in this article.

\subsection{Technical assistance for improving the voice of deaf people}

To perform their duties and routine activities, people with deafness exploit other adjacent senses (BARBACENA, 2010), i.e. the union of senses such as speech, vision and tact consolidate the perceptual process (KING; CALVERT, 2001).

As already mentioned, one of the many consequences raised by hearing impairment, stands out the problems in the development of spoken language, caused by difficulty of sound perception, a fact which leads to the subject of lack of monitoring the sound with the hearing sense, which highlights that "hearing and language are correlated and interdependent functions" (GATTO \& TOCHETTO, 2007). According to PEREIRA (2013), all the biological conditions for voice production are present in a deaf person, except the hearing feedback for monitoring the same.

Currently, the improvements in PSAP and in some clinical procedures as $\mathrm{Cl}$, which consists of an electronic prosthesis introduced through surgical procedure in the inner ear that directly stimulates the auditory nerve, so that this device carries out part of the functions of sensory cells in the cochlea, are considered promising alternatives to the rehabilitation of the hearing impaired.

When it refers to devices with especially educational purposes (classroom), it can be mentioned the FM system as a fairly efficient equipment, but still expensive and inaccessible, consisting of a receiver that when coupled to the PSAP, contributes to the reduction of environmental noise, allowing sound fidelity and little possibility of interferences from unwanted sounds.

Auxiliary hearing electronic resources and other artifacts resulted from academic research and are based on the principles of assistive technology are optimizing the use of residual hearing, i.e. some facilitator tools and clinical procedures arise to audiology professionals helping the impaired that do not show total loss of auditory functions to acquire, through therapies, spoken skills (ALVES, SOARES \& OLIVEIRA, 2014). 
With regard to subsidies that professionals speech therapy and educational audiology have available, highlights that "existing tools, although effective, not sufficient to ensure the oral communicative approach" (ALVES, SOARES \& OLIVEIRA, 2014, p. 2). Thus, many academic works (MENDES, FERREIRA and CASTRO, 2012; BOERSMA \& WEENINK, 2011; BEHLAU, 2012) investigate the possibility of developing systems for acoustic analysis of vocal parameters with non-invasive character, and that overcome some shortcomings observed in the current tools and techniques.

Some previous studies on oral approaches of deaf individuals deal with the evaluation and voice coding, as well as a form of feedback to correct the parameters identified by means of tactile stimuli. BARBACENA (2010) proposes the development of a real-time system for teaching/learning of fundamental frequency of speech, in which he used a signal generator to trigger the vibrotactile stimulator, with command sent by the software that runs on a computer the beginning of training. The findings of the referred author in the context of voice coding were used as theoretical basis for this work, but stands out that the hardware used for the implementation of the project presents different particularities, especially regarding the need to have a reduced floor space inside the device, this constraint supplied by this study, since the FPGA consists of an integrated circuit contained in a didactic kit for development and testing. The referred author searches a significant improvement in the oral process through some techniques of tactile stimulation.

It is worth to note that among many methodologies geared to the process of improvement and control of speech, highlights that based on correction of the voice fundamental frequency of the deaf through training with visual feedback (ARAÚJO, 2000), as well as training of lip reading and speech perception through tactile stimulus transmission of information on the fundamental frequency of the voice (EBERHARDT et al., 1990). More recent studies reinforce such approaches in terms of tactile stimulation (CUNHA, 2012).

Although some research prove the feasibility of the use of touch and vision to the voice improvement therapies, "the question of integrating the use of visual and tactile feedback is still an open discussion" (BARBACENA, 2010, p. 131), and can be widely used. Therefore, there is a gap to be filled with respect to creation of methodologies that help in the perception and understanding of the speech through such stimuli, thus promoting changes in activity of communication through the use of hearing devices that are compatible with the deficiency degree of specific user (SPERI, 2013).

\section{METHODOLOGY}

This research proposes the development of a device for acoustic analysis of the voice and oral improvement of the deaf. In short, the work consists in the implementation of a system that captures voice signals, besides performing the processing, extraction of parameters and the tactile and visual feedback simultaneously, operating in real time. The whole system has been configured in an electronic component called FPGA that is an integrated circuit consisting of thousands of transistors and basically does what multiple integrated circuits would, with the difference that its matrix can be reprogrammable. In this way, a very high speed integrated circuit hardware description language (VHDL) for the logic construction of this project was used.

The proposed study, system and data begin from a survey developed for doctoral work of one of the authors of this article. The database that is also from the already mentioned work, was 
composed of a number of 96 samples of voice signals, in Portuguese language, in different stages of intervention for the assessment of speech quality improvement by controlling/learning the fundamental frequency. For the identification of the best tactile sensitivity in specific locations of the body, still counted on the results of the investigation with 238 volunteers. The presence of a translator, with the use of sign language, was required to give fluidity to the experiments.

Descriptive statistics was used to scale the information regarding the aspects involving the profile of the volunteers, the locations of the body with better tactile sensitivity to stimulation and the results of an evaluation of the improvement of vocal characteristics analyzed in pre and post intervention steps with the proposed system. The following topic specifies important discussions of the development, implementation and testability of the proposed device that makes use of the visual-tactile stimulation.

\subsection{Development of visual-tactile stimulation device}

In the acquisition of voice, as well as response to tactile stimuli, the sign after being captured and rendered on the reconfigurable device shows the result in real time of the $F_{0}$ in an LCD display, present on the hardware used, and such output works simultaneously with the tactile actuator, so that the user can feel the pattern vibrations as indication of right or not the target that corresponds to the normal frequency, thus stimulating the perception of participants and evaluating whether there have been significant changes in the vocal skills of temporal order and sequence after intervention with the system here developed.

The volunteers involved in the study after previous learning of the target frequency prior are more likely to perceive the differences of the vibration actuator, placed at the fingertip. Thus, the individual may support a tool able to assist him in the necessary target switching, as well as its maintenance, in addition, allows for a response to the user about the sound produced at any given time so that way the same can fix it, if applicable.

The project was implemented in the Mercurio ${ }^{\circledR}$ IV development kit, from the manufacturer ALTERA, shown in Figure 1-a. This board has a FPGA EP4CE30F23C7 of family Cyclone IV, and has 30 thousand of logical elements and a clock-input of $50 \mathrm{~Hz}$. The necessary materials to test the validation of the system were a microphone for capturing the voice signal, a laptop with the Quartus II development software and a vibrotactile actuator, as shown in Figure 1-b.

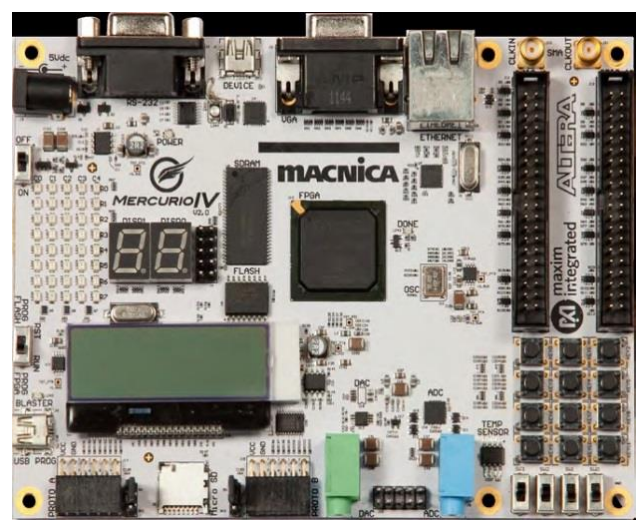

a)

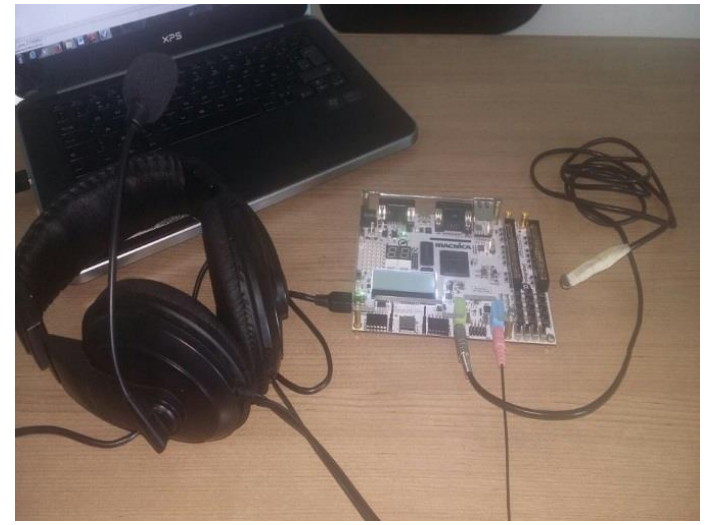

b)

Figure 1: Project development - a) FPGA Development kit; b) Design scheme 
The system involves steps ranging from the acquisition of voice signal, through the implementation of filters, serial communication module, FFT calculation and estimation of pitch, comparison to benchmarks and the transformation and codification into VHDL from voice signals to tactile stimuli. In this case, the reference is to hit a particular vibration intensity, which is taught to the individual.

Simultaneously with the tactile output, a visual module starts working, that is, the change of values is displayed on the LCD display and the hit turns on a LED RGB. Thus, while the LED is with the green segment turned on, it means that the individual is hitting its target frequency, however, if there is a variation for the red color on the LED, the person is farther to hit, so he needs to treat such parameter. At first, the patient should be trained to learn the default vibration for normal individuals of the same age group and gender, and that way could be seen that when the actuator is vibrating with intensity greater than what is taught, there is an error indication, because the frequency is above the standard with detachment of expected $F_{0}$, also called the target frequency. When vibrating with less intensity, indicates that the frequency of that user is below the target.

The block diagram in Figure 2 illustrates the algorithm steps for extraction of pitch and its conversion to the tactile output.

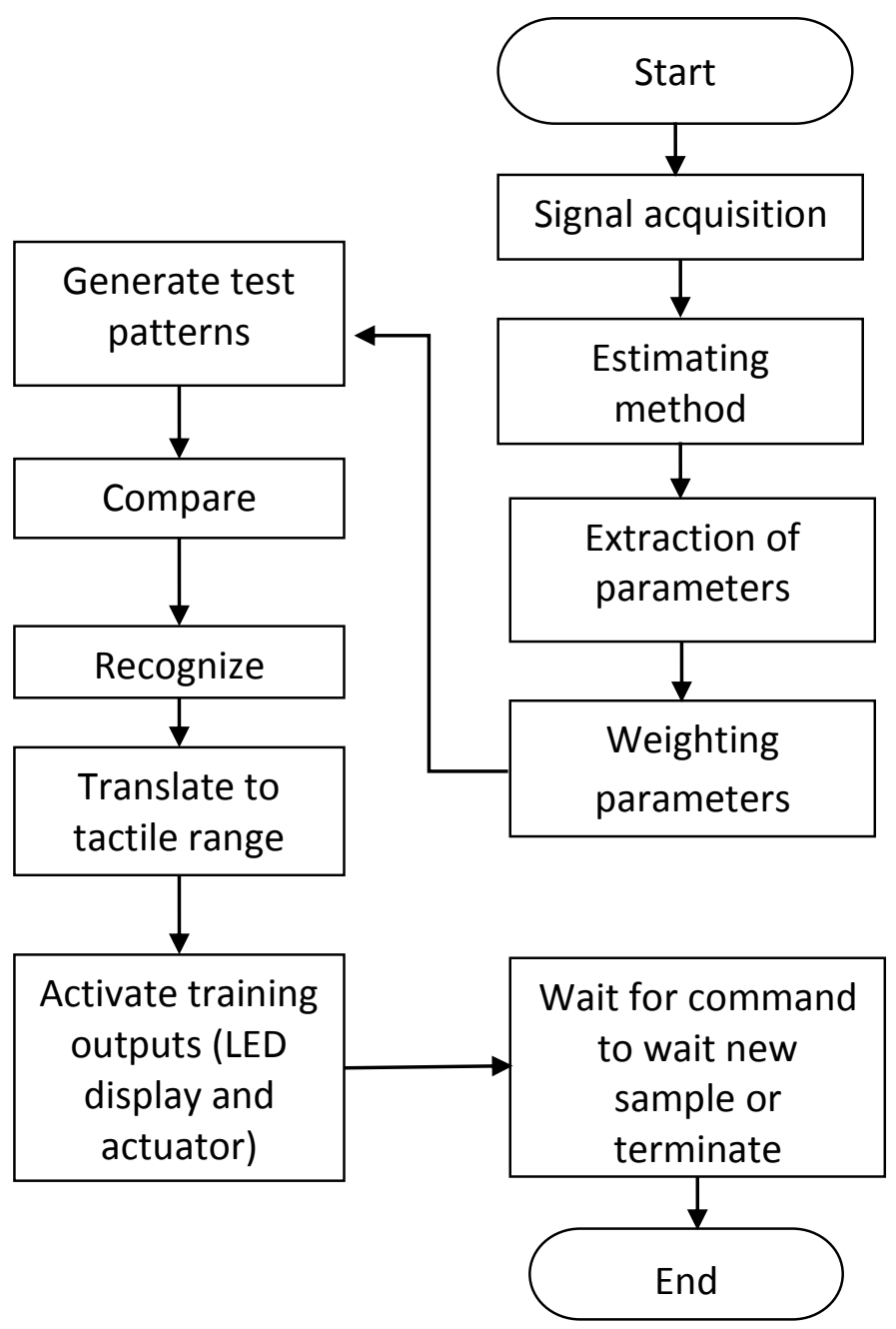

Figure 2: Block diagram of the algorithm for extraction of pitch 
Briefly, the method was based on signal acquisition, where the described initial code techniques prepare the signal to be segmented, divided into smaller parts. A digital filter called low-pass was used to mitigate signal components with frequency above the maximum allowable frequency, thus preserving the data of the input signal. Thereby, the filtered signal is routed to the estimate block that applies the necessary functions to the voiced and deaf signal segments and, subsequently, it is estimated the pitch depending on the position of the peak signal and the values are directed to the weighting block, where the values were measured and classified.

The parameter extraction methods have a kind of database, i.e. information of prediction coefficients obtained and stored in a structured way. Subsequently, the implementation proceeds with the generation of test patterns using measures of distance and vector quantization method for reference standards already archived properly, thereupon, after extraction of the features, a set of reference standards are created in the stage considered as training, these standards serve as a basis for comparison and for recognition in order to ensure that certain decisions are taken. With the generation of test patterns, the signal is manipulated and compared with the references. In the stage of pattern recognition, the system returns the results of possible outputs. Thus, once performed the comparison and obtained the results, the application of speech encoding for tactile range is made, sending such a frequency range to the actuator, which consists of one of the system outputs that operates synchronized with the LED and display (other training outputs).

The importance of working with programmable logic devices lies in the possibility of creating a digital circuit that can be changed at any time with the same physical hardware, by simply reprogramming the device, i.e. developing the project with a high level of flexibility, using the same physical medium, but whenever it is necessary to change it, simply use the reprogramming of the FPGA component.

\section{RESULTS}

The result analysis prioritized the data description and central tendency. The findings are presented below and indicate correlation with other approaches carried out in previously developed studies that are also described in the literature. All data collected in the tests were evaluated using statistical treatment.

On the criterion of sample classification, it is highlighted that for evaluation of tactile sensitivity, the population was composed of a number of 238 volunteers, being 83 with hearing impairments and 155 that showed normal hearing, and the body parts examined to check which presents a greater tactile sensitivity were: thigh, forearm and fingertips, because knowing such aspect, it is possible to collaborate more efficiently for the transmission of information through the sense of touch, as a sensory substitution feature in real time to the people with hearing and/or visual impairment.

In order to verify the behavior of fundamental frequency and phonation time in the issuance of three sustained vowels $(a, e, i)$ and continuous speech, in the pre and post intervention steps with the developed visual-tactile stimulation system, the voice signal of 96 volunteers was captured, and from this total, 12 are adult male, 27 are adult female, 15 are adolescent male, 18 are adolescent female, and 24 are children. These subjects were divided into groups according to the criteria of gender and age group. 
By analyzing the aspects of the body part where the individual presents best tactile perception, the present work brings a comparison between tactile sensitivity as a function of the contact areas of the stimulator device and three vibration frequency bands of the stimulator, which are $17.8 \mathrm{~Hz}, 31.6 \mathrm{~Hz}$, and $56.2 \mathrm{~Hz}(\mathrm{f} 1, \mathrm{f} 2$, and f3, respectively), for the procedure performed in 238 volunteers, thereby, the research and analysis of sites with best answers in the test participants were performed. Such frequency bands were used because the tactile sensitivity varies in a logarithmic scale that ranges from $10 \mathrm{~Hz}$ to $100 \mathrm{~Hz}$, which according to SADATOA et al. (2004) represent the best sensitivity ranges. Then, strictly speaking, when splitting the logarithmic scale in equally-spaced points, such values that must be used in programming and activation of actuator are obtained.

The vowels /a/, /e/, and /i/ were chosen because they are more easily emitted by any group of people, furthermore, some studies present these vowels as important for the analysis of acoustic patterns (PEREIRA, 2013). But the analyzed body parts include locals that had not been widely compared with each other, bearing in mind that is common to note the sensitivity in different fingers (BARBACENA, 2010) and it is relevant to review such parts to the search of alternative systems that can be applied in different body areas, emphasizing the region that presents the greatest potential for stimulation. The results in Figure 3 show the average percentage of hit behavior in the three analyzed body parts, in function of each frequency band.

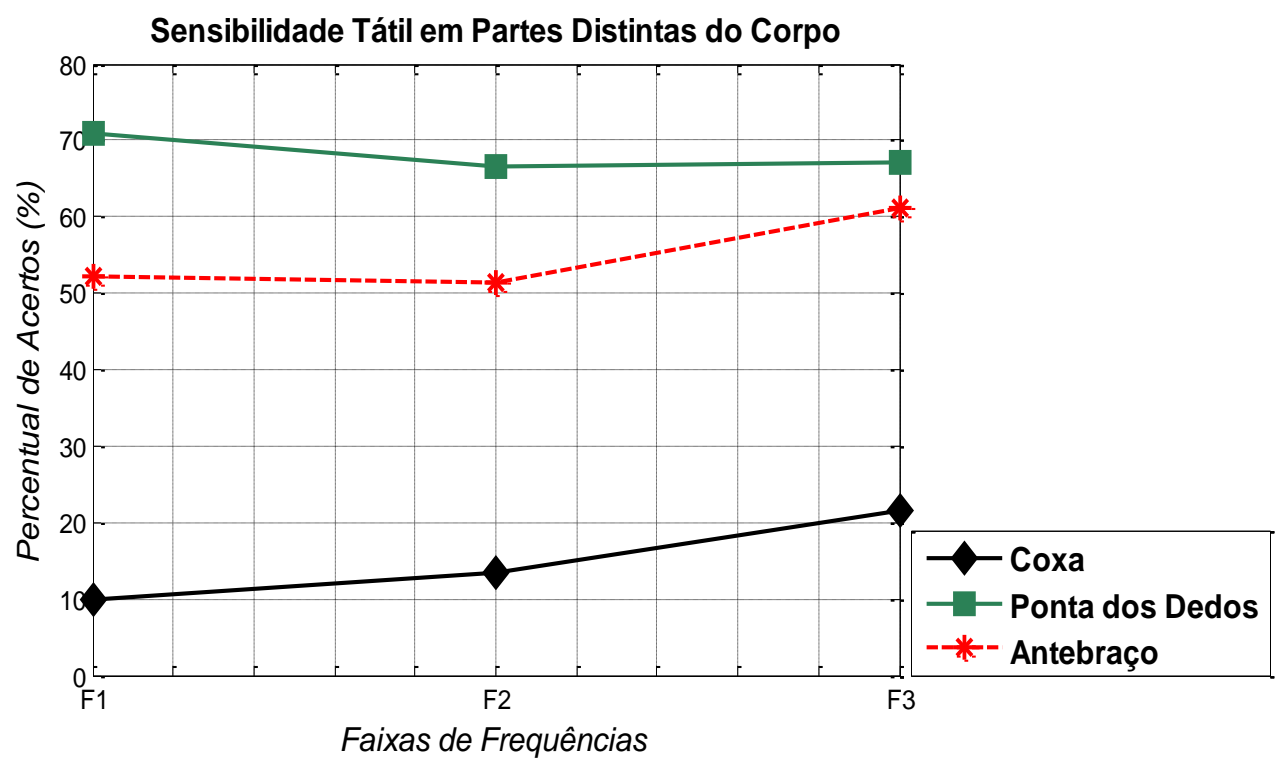

Figure 3: Tactile sensitivity in specific parts of the human body

The results schematized in Figure 3 corroborate with the findings described in the literature (CUNHA, 2012) on fingertips as the region of greater sensitivity, obtaining in this part the best answers to the three adopted target frequencies. As can be seen, the average percentage of hits in fingertips were in function of $f 1, f 2$, and $f 3$, respectively equivalent to $70.89 \%, 66.67 \%$, and $67.08 \%$, higher than hits in other body parts. Although there has not obtained percentage hit significantly high, points out that this factor does not cover a limitation of the project, because it cannot be affirmed that certain stimulation technique is faithfully reliable, that is, there is not an algorithm that enables $100 \%$ of hit (ROUAT et al., 1997), then the observed values were satisfactory in the context in question. 
In general, high sensitivity was observed in the forearm, and the results were significantly close to the fingertips, in a percentage of $52.11 \%$ (in function of $\mathrm{f} 1$ ), $51.48 \%$ (in function of $\mathrm{f} 2$ ), and 61.18\% (in function of $\mathrm{f3}$ ). However, the lowest potential for tactile sensitivity occurred in the region of the thigh to the three adopted frequencies, with a percentage hit lower than the locations analyzed, being on average equal to $9.91 \%, 13.5 \%$, and $21.52 \%$ for the vibration frequencies of $17.8 \mathrm{~Hz}, 31.6 \mathrm{~Hz}$, and $56.2 \mathrm{~Hz}$, respectively. Thereby, at first, it is worth highlighting that such a result, particularly the best answers at fingertips were already expected, because getting in line with the work of CUNHA (2012), the quality of this region by virtue of its peculiarities is notable.

In order to make room for an argument that defines the possibilities of development of tools to different body parts, as well as the different types of users, regardless of gender and disability, for a comparative analysis, set up a database to verify aspects of the differences in the perception and sensitivity of thresholds with respect to body parts of the female and male volunteers.

In addition, it is important to assess whether factors such as gender, age, disability and other aspects influencing the results. As a result, it was compared the average percentage of hits for each studied body part also for the two groups: the deaf and people without disabilities, being the test applied to the entire population, corresponding 83 deaf and 155 listeners.

The data found for the two genders, as well as for the group of deaf and listeners, show that both categories showed better resolution of touch in the light of all the frequency bands at fingertips, followed by the forearm and lower discrimination in the thigh. The percentage values of hits are arranged in the Table 1.

Table 1: Comparison of the percentages of hits

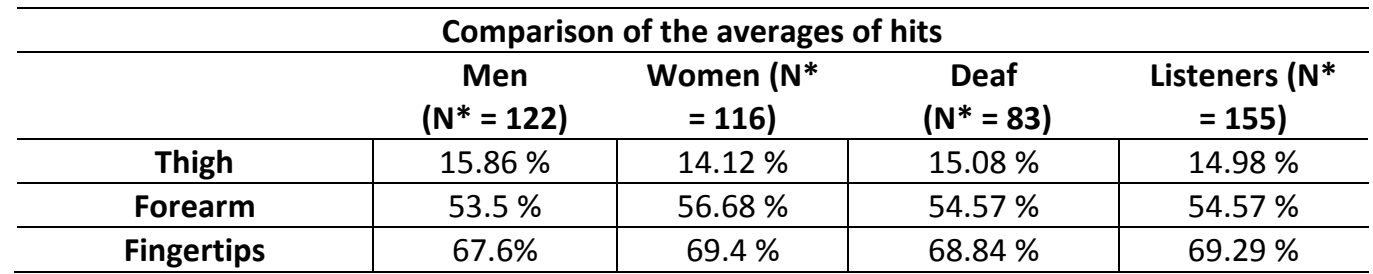

Source: Research results (2015).

Notes: ${ }^{*} \mathrm{~N}$ is equal to the number of individuals in the group.

Still according to Table 1, it is observed that in the region of the thigh, the men hit in attempts was on average of $15.86 \%$, women showed a percentage of $14.12 \%$; At fingertips, the average obtained for men corresponded for $67.6 \%$ and $69.4 \%$ for women; Inside the forearm had $53.5 \%$ and $56.68 \%$ for men and women respectively.

In general, the responses of skin receptors both in men as in women decrease in the opposite direction the ends of fingers, i.e. obtain better discrimination at the ends of the fingertips, such vibrotactile perception decreases in the forearm and becomes even smaller in the thigh.

It is note that the total hit in the thigh, in the case of analysis with deaf individuals, were $15.08 \%$, but the listeners achieved an average of $14.98 \%$. At fingertips were $68.84 \%$ and $68.29 \%$ for deaf and listeners respectively and the forearm was equally $54.57 \%$ of hits, for hearing impaired and volunteers with normal hearing.

Vibrotactile stimulation as alternative method of communication to be effective needs to take into consideration its basic dimensions, such as frequency, amplitude, duration and better 
body part to apply the vibrations (BARROS, 2004). Thus, according to the findings, the part that will provide the best results in terms of perception is at fingertips, for this reason, the potential of tactile sensitivity was explored in that body part for testability emphasized in this work.

Since then, the focus was the acoustic analysis of vocal parameters and subsequent correction. A characteristic of the voice signal processed on the device developed and evaluated initially was the maximum time of phonation for emitting three vowels $(a, e, i)$ that corresponds to the maximum time, in seconds, for the emission of a sound or speech, sustained by an individual in a single expiration, as illustrates the Figure 4.

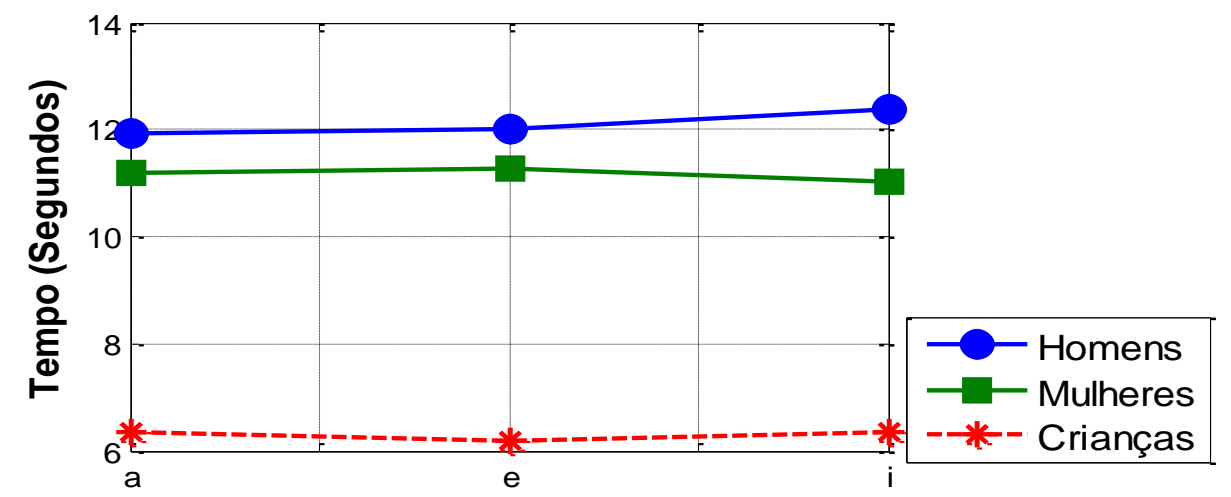

Figure 4: Phonation time in Pre-intervention step

With regard to the maximum time of phonation, normality patterns defined are 20 seconds for men, 14 seconds for women, and around 10 seconds for children (CHRISTMANN et al., 2015; MENDONÇA, SAMPAIO and PROVENZANO, 2012). As illustrated in Figure 4, in pre-intervention step, i.e. at the stage in which they analyzed the average values of phonation and voice fundamental frequency without prior training, it is observed that the maximum time of phonation in seconds of the children involved in the study is on average $6.33 \mathrm{~s}, 6.17 \mathrm{~s}$, and $6.36 \mathrm{~s}$ to vowels $/ \mathrm{a} /$, $/ \mathrm{e} /$, and /i/, respectively; In men, following the same sequence of vowels were $11.93 \mathrm{~s}, 12.01 \mathrm{~s}$, and 12.36s. But in women were $11.17 \mathrm{~s}, 11.29 \mathrm{~s}$, and 11.01s.

Subsequently, for a comparative approach, a measurement of phonation times was performed after the intervention and training for the same groups. Figure 5 externalizes the results on post-intervention step.

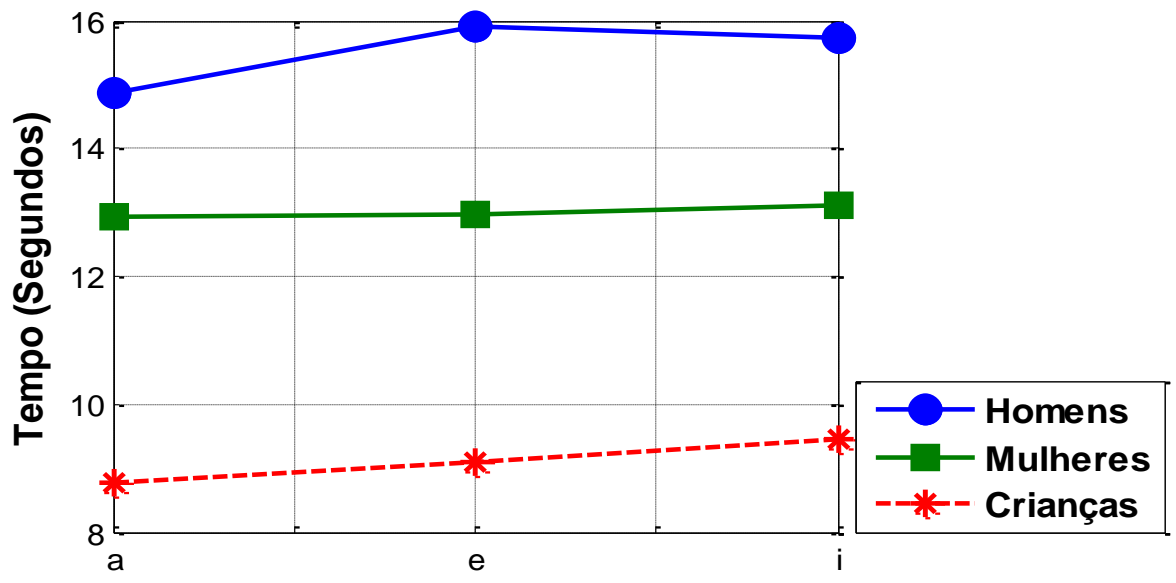

Figure 5: Phonation time in Post-intervention step 
According to the data obtained and illustrated in Figure 5, it is note that after the auditory training and frequency control by means of stimulation there was an improvement in the ability to sustain for a longer time the emission of vowels, since the times of phonation for vowels /a/, /e/, and $/ \mathrm{i} /$, in the post-intervention step were on average and respectively $14.86 \mathrm{~s}, 15.92 \mathrm{~s}$, and 15.73s, for male individuals; in women the values for the three vowels were equivalent to $12.93 \mathrm{~s}, 12.97 \mathrm{~s}$, and $13.12 \mathrm{~s} ;$ In the group of children was observed on average $8.77 \mathrm{~s}, 9.10 \mathrm{~s}$, and $9.47 \mathrm{~s}$.

As it is well known, in the men group such a measure should be around 20 seconds (CHRISTMANN, et al., 2015; MENDONÇA, SAMPAIO and PROVENZANO, 2012), then values were much lower based on pre-intervention data, having an increase on post-intervention to all phonemes analyzed in the test, which shows the methodology effectiveness, when training is constantly evaluated, since although the values in the second stage still distant a little from the established patterns, these had a significant maintenance of their measurements with increased times. In women, there is maintenance time, cannot be considered that there was a high change in this case, because the values between the pre-intervention and post-intervention do not differ greatly, however, there has been an increase and the values reached levels closer to $14 \mathrm{~s}$, as expected (CHRISTMANN et al., 2015; MENDONÇA, SAMPAIO and PROVENZANO, 2012) for the subject of the group.

The analysis with children presents some peculiarities, because in this group the intensity of speech is still an undefined pattern, and for this reason, so difficult to be analyzed. It is note that with respect to the times demanded for the emission of the vowels, the best performances obtained occurred after the intervention procedure for all participants of category. It is worth highlighting that skills of support time were considered appropriate to the age of the subject and to training developed, however, in virtue of the infant anatomy, accurate results are not always possible.

An increase in the phonation time is a therapeutic evolution in the evaluation process, because it influences the speech quality. Thus, after such notes, it is relevant to mention the major discussions on the observation in each group of the communicative skills of the volunteers, that is, the values found for the $F_{0}$ and standard deviation measurements in order to be possible to verify the behavior of the variability in the performance of the sample, taking into account the standards adopted for the different categories of participants before and after the proposed intervention method. The values adopted for the target frequency that indicate normality were the following: $120 \mathrm{~Hz}$ for adult men, $200 \mathrm{~Hz}$ for adolescent male between 11 and 17 years old, $220 \mathrm{~Hz}$ for adult women, $250 \mathrm{~Hz}$ for adolescent female, and $300 \mathrm{~Hz}$ for children (BARBACENA, 2010).

Table 2: Fundamental frequency for vowels in pre-intervention

\begin{tabular}{|c|c|c|c|c|c|c|c|c|}
\hline \multirow{2}{*}{\multicolumn{2}{|c|}{ Groups }} & \multirow{3}{*}{$\begin{array}{l}\mathbf{N}^{*} \\
27 \\
\end{array}$} & \multicolumn{3}{|c|}{ Average frequency } & \multicolumn{3}{|c|}{ Standard deviation (SD) } \\
\hline & & & \multirow{2}{*}{$\begin{array}{c}\begin{array}{c}F_{0} / \mathrm{a} / \\
\text { (Hz) }\end{array} \\
233.75 \\
\end{array}$} & \multirow{2}{*}{$\begin{array}{c}\begin{array}{c}F_{0} / \mathrm{e} / \\
(\mathrm{Hz})\end{array} \\
234.84\end{array}$} & \multirow{2}{*}{$\begin{array}{c}\begin{array}{c}F_{0} / \mathbf{i} / \\
(\mathbf{H z})\end{array} \\
234.93 \\
\end{array}$} & \multirow{2}{*}{$\begin{array}{l}\text { SD /a/ } \\
19.20 \\
\end{array}$} & \multirow{2}{*}{$\begin{array}{c}\text { SD /e/ } \\
19.43 \\
\end{array}$} & \multirow{2}{*}{$\begin{array}{l}\text { SD /i/ } \\
19.01\end{array}$} \\
\hline & Fem. & & & & & & & \\
\hline Aaurts & Male & 12 & 125.6 & 130.15 & 131.3 & 15.14 & 12.7 & 12 \\
\hline \multirow{2}{*}{$\begin{array}{c}\text { Adolescents } \\
\text { (11 to } 17 \text { years) }\end{array}$} & Fem. & 18 & 258.37 & 257.46 & 258.06 & 23.8 & 22.9 & 22.6 \\
\hline & Male & 15 & 152.68 & 154.36 & 155.56 & 40 & 38.4 & 29.2 \\
\hline Children & Both & 24 & 295.2 & 297.33 & 300.75 & 24.3 & 24.1 & 22.1 \\
\hline
\end{tabular}

Source: Research results (2015).

Notes: ${ }^{*} \mathrm{~N}$ is equal to the number of individuals in the group. 
In pre-intervention step, each participant was instructed to perform oral emissions of indicated vowels without prior training, just receiving the necessary explanations about the study, functionality and purpose of the investigation. In this context, the Table 2 externalizes the results of analyses in pre-intervention step.

It is possible to notice that among the female adults, an increase in the values of the fundamental frequency was identified, being the referred aspect $13.75 \mathrm{~Hz}, 14.8 \mathrm{~Hz}$, and $14.93 \mathrm{~Hz}$ above expected average for the group in the emission of vowels /a/, /e/, and /i/, respectively, which represents the respective error percentages of $6.25 \%, 6.74 \%$, and $6.79 \%$. Furthermore, there is a significant variability between the averages of the sample, demonstrated by the values of the standard deviation. In the testability stage of the practical implementation of the project, the average participation in the experiment was of 30 minutes a day for a period of three weeks in supervised sessions for the individual understands the functionality of the system.

In the case of male adults, it is highlighted that the vowels /a/, /e/, and /i/, in this sequence, the estimated values in $\mathrm{Hz}$ for frequency of the voice were5.6 Hz, $10.15 \mathrm{~Hz}$, and $11.3 \mathrm{~Hz}$, above the normality measure to the group, leading to the following error percentages for each of the vowels: $4.67 \%, 8.46 \%$, and $9.42 \%$.

It cannot be disregarded the interesting revelation that among male adolescents there was no error percentage, considering that their frequencies were within the values considered normal, however, by the standard deviation analyzed can be inferred that there was greater variability of averages among groups of the step in emphasis. A similar situation occurred with the children, because only one of the participants presented a value of $0.75 \mathrm{~Hz}$ higher than expected, representing a $0.25 \%$ error. In the adolescent group also occurred a small elevation of the measures, being $8.37 \mathrm{~Hz}$ in vowel /a/ (3.35\% error), $7.46 \mathrm{~Hz}$ in vowel /e/ (2.99\% error), and $8.06 \mathrm{~Hz}$ in vowel /i/ (3.22\% error).

Strictly speaking, to validate the actual assistance and performance of purpose, volunteers have undergone some training for learning the standard frequency by means of rehabilitation with tactile actuators, for carrying out the second stage of the study or post-intervention, in order to verify the improvements, that is, if there were changes in the oral skills of subjects with the reduction of $F_{0}$. The results obtained in step in question can be viewed in Table 3 .

Table 3: Fundamental frequency for vowels in post-intervention

\begin{tabular}{|c|c|c|c|c|c|c|c|c|}
\hline \multirow{2}{*}{\multicolumn{2}{|c|}{ Groups }} & \multirow{3}{*}{$\begin{array}{l}\mathbf{N}^{*} \\
27 \\
\end{array}$} & \multicolumn{3}{|c|}{ Average frequency } & \multicolumn{3}{|c|}{ Standard deviation (SD) } \\
\hline & & & \multirow{2}{*}{$\begin{array}{c}\begin{array}{c}F_{0} / a / \\
(H z)\end{array} \\
218.64\end{array}$} & \multirow{2}{*}{$\begin{array}{c}\begin{array}{c}F_{0} / \mathrm{e} / \\
(\mathrm{Hz})\end{array} \\
225.44 \\
\end{array}$} & \multirow{2}{*}{$\begin{array}{c}\mathrm{F}_{0} / \mathrm{i} / \\
(\mathrm{Hz})\end{array}$} & \multirow{2}{*}{$\frac{\mathrm{SD} / \mathrm{a} /}{16.3}$} & \multirow{2}{*}{$\begin{array}{c}\text { SD /e/ } \\
12.9\end{array}$} & \multirow{2}{*}{$\begin{array}{c}\text { SD /i/ } \\
9.77\end{array}$} \\
\hline Adults & Fem. & & & & & & & \\
\hline Aduils & Male & 12 & 113.75 & 114.35 & 114.35 & 8.17 & 4.57 & 4.63 \\
\hline \multirow{2}{*}{$\begin{array}{c}\text { Adolescents } \\
\text { (11 to } 17 \text { years) }\end{array}$} & Fem. & 18 & 244.16 & 243.83 & 241.96 & 23.2 & 20.1 & 14.1 \\
\hline & Male & 15 & 131.92 & 137.16 & 146.16 & 35.8 & 32.4 & 30.3 \\
\hline Children & $\begin{array}{l}\text { Both } \\
\text { sexes }\end{array}$ & 24 & 294 & 287.45 & 278.8 & 23.5 & 22.4 & 20.9 \\
\hline
\end{tabular}

Source: Research results (2015).

Notes: ${ }^{*} \mathrm{~N}$ is equal to the number of individuals in the group. 
According to the information contained in Table 3, on post-intervention step is noted that the achieved measures show the increase hit averages among groups, i.e. after the application of the procedure described, there was a reduction of the fundamental frequency of the voice. It points out, however, that among adult women, on average, the intended target was not reached, since the emission of the vowels /e/ and /i/ showed an error of $2.47 \%$ and $1.51 \%$, respectively, but there was a significant decrease, with only the same frequencies $5.44 \mathrm{~Hz}$ (/e/ vowel) and $1.51 \mathrm{~Hz}$ (/i/ vowel) above the standard, a much reduced compared to those obtained in pre-intervention step, which were $14.8 \mathrm{~Hz}$ and $14.93 \mathrm{~Hz}$. On the other hand, all other groups have reached an expected or approximated pattern within the normal range. In addition, the values of standard deviations show less variability between the measures of the sample, after training with the described visual-tactile stimulation system.

The analysis of fundamental frequency in continuous speech is a relevant alternative, however, it is not an easy task. In this context, a speech encoding process in such a situation was performed, which in fact needs to be refined in subsequent studies because of its complexity. Thus, the values shown in the display and the tactile stimuli vary continuously as there is a voice being emitted. In this way, the implemented algorithm contains a block for the average calculation of the estimated values along the voiced emissions, avoiding errors that compromise the final results. The test sentences did not represent a pattern in this work, then it was requested only that each subject pronounce its full name. The approach with specific sentences and other isolated phonemes can be treated in future studies for enhancement of the device.

The average of expected $F_{0}$ varies according to age and gender of the speaker. In this sense, as already mentioned, the foreseen default values were: $120 \mathrm{~Hz}$ for adult men, $200 \mathrm{~Hz}$ for adolescent male between 11 and 17 years old, $220 \mathrm{~Hz}$ for adult women, $250 \mathrm{~Hz}$ for adolescent female, and $300 \mathrm{~Hz}$ for children, because these measures are acceptable in the major studies cited in this article. Thus, in Table 4 is shown a description of the main results obtained on the values of the fundamental frequency of the voice with continuous speech, having as support the visualtactile correction system, in a comparative approach in the moments before and after the training.

Taking into account the sample of adult male involved in research, in the first moment of the procedures with the voice, the average extracted fundamental frequency was $126.8 \mathrm{~Hz}$ with $5 \%$ error in relation to the target and had a decrease of 12.55 after training, reaching an average of $114.25 \mathrm{~Hz}$, with no percentage error. In the women group, it was also noted a significant improvement in voice control after training with the actuator. The average frequency obtained without previous training was $236.44 \mathrm{~Hz}$, with percentage error of $7.47 \%$, therefore, the value of $F_{0}$ was reduced to $218.55 \mathrm{~Hz}$ after training.

Table 4: Fundamental frequency average for continuous voice

\begin{tabular}{c|c|c|c|c}
\hline \multirow{2}{*}{} & \multicolumn{2}{c}{ Pre Intervention } & \multicolumn{2}{c}{ Post Intervention } \\
\cline { 2 - 5 } & Male & Female & Male & Female \\
\hline Adults & $126.8 \mathrm{~Hz}$ & $236.44 \mathrm{~Hz}$ & 114.25 & 218.55 \\
\hline Adolescents & $148.84 \mathrm{~Hz}$ & $258.36 \mathrm{~Hz}$ & $156.16 \mathrm{~Hz}$ & $236.73 \mathrm{~Hz}$ \\
\hline $\begin{array}{c}\text { Children } \\
\text { (Both sexes) }\end{array}$ & \multicolumn{2}{c}{$295.57 \mathrm{~Hz}$} & \multicolumn{2}{c}{$274.22 \mathrm{~Hz}$} \\
\hline
\end{tabular}

Source: Research results (2015).

With regard to adolescents, as shown in Table 4, the estimated values for the average frequency in pre-intervention step were equivalent to $258.36 \mathrm{~Hz}$. In the post-intervention step 
there has been a reduction of 21.63 on the value of $F_{0}$ average, which reached $236.73 \mathrm{~Hz}$, thus eliminating the percentage error.

It is noticed that the children voice show specific characteristics and in the present study reached an expected threshold within the normal patterns, with no percentage errors in both moments of stimulation. Some considerations that can be made is that the averages found for such a group does not run counter to some measures defended in the literature, so that the same show high fundamental frequency and some inadequacies in intonation.

In this context, the task proposed in the present work introduces the proceeds and the questioning effects on new forms of transformations for the codification of fundamental frequency and its transmission through the tactile sensation. The presence of this resource generates opportunities for professional growth and amplification of the developed work. Their influences may affect not only the analysis of fundamental frequency, but also in other vocal characteristics of the individual, as a phonological intervention technique.

Although presenting effective results, non-invasive character and accurate analysis, it is important and essential the accompaniment of a voice specialist, classifying the performances obtained by the continuous use of the device and all aspects related to the improvement of the voice quality. Many current speech therapy and teaching of speech techniques are based on the oral reproduction of phonemes and words, thus, the tactile and visual tracks show up as allies in this type of therapeutic educational method. The device comprises an auxiliary resource available to the speech therapist, so that enables the user to test the skills during training, because the proposed educational-clinical method contributes to the adoption of new approaches and technical assistance in the teaching of speech, which not dismiss the partnership of educators, families and health professionals to the success of the assistive technology developed in the process of analysis and correction of the fundamental frequency of the voice.

\section{CONCLUSION}

The present work had as priority objective the development of a process for improvement and control of speech through the implementation of a system that uses the visual-tactile feedback for learning, control and correction of the fundamental frequency of the voice, and even capable of performing a capture and analysis of vocal parameters in real time on a reconfigurable FPGAtype device, evaluating new forms of voice encoding in tactile stimuli, in addition to an acoustic analysis of non-invasive character for those involved.

Pragmatically, with the validation of the proposal, the observations indicate the relevance of the analysis of vocal signs and their respective parameter extractions in reconfigurable FPGAtype devices. From the resources and materials used, as the FPGA component, the high level description language VHDL and the participation of deaf individuals with speech disabilities, who are the target audience, it can be noted that the particularities of programmable logic devices and the surprises of working with these components, require systematic studies in order to make possible, in future works, greater advance and improvements in aspects of the system contemplated for basic attention to integrated and tailored creations regarding the development of assistive technologies. 
In the present context, the integration of the use of visual and tactile feedback, in fact meets the needs for which it was designed, bearing in mind that the continued use of such a system enables the reduction in fundamental frequency, as well as a significant increase of the maximum times of phonation of sustained vowels /a/, /e/, /i/, and continuous voice, promoting hence the improvement in correction and control of intonation and effective perceptual ability of speech.

It can be concluded that there was a noticeable reduction in the values of $F_{0}$ between the groups in the post-intervention step as compared to the pre-intervention, at which point those involved had not received prior training with the described system. Generally speaking, in the adult group, the men showed a decrease in the frequency measures relatively more significant than women, moreover, among the involved children, it was evidenced that the frequency is lower the higher the age of the individual. It is concluded that the gender (except in children) and age group influence on the results of the measures found in the evaluations.

In general, the support of the tactile and visual stimulation simultaneously to oral production is of high relevance to support the therapeutic oral procedures, with applicability evidenced in training of perceptual skills and improving the voice quality for people with hearing disabilities of different levels. An increase in user training time should be better studied in order to realize the effective improvement and stabilization of the fundamental frequency of the voice, besides verifying a better learning curve.

The found results, even in a short period and with a small number of tests, showed the accuracy in capturing the frequency and how the improvement of this study can contribute significantly in the process of stimulating in academic papers, research that promote alternatives in the development of new analysis and correction of vocal characteristics in patients with hearing disabilities.

This work makes real contributions to areas that involve the oral improvement, not to mention the blocks of codes created that can be applied to later acoustic and perceptual analysis techniques, corroborating to the diagnosis and correction of speech complications caused by change in $\mathrm{F}_{0}$. It is worth highlighting that the proposal expressed here is a resource that can serve as a support for professionals in the field of speech therapy and educational audiology, as well as for those who have the voice as an instrument for work and need to keep it in a specific pattern. Thus, it shows as a viable and effective alternative, and low cost for the implementation of digital signal processing systems.

Finally, it is suggested the performing of comparative studies for refinement of the system, so that they can investigate the possibility of new forms of encoding for training in continuous speech, because it is not a relatively easy method to capture the variability present in the signal, which requires repeated and systematic studies. Additionally, it would be interesting the insertion of new features and commands to the described circuit, so that way new vocal classification algorithms could be exploit, making possible to work with various aspects extracted from captured voice signals. It is still necessary to conduct tests of frequency correction in other languages for comparison with the results obtained with the Portuguese language.

As limitations, it should be noted that the conclusions of the study are local, given the amount of experiments and particularity of the sample, with the need to expand the results for other segments and evaluation of new parameters for work continuity, and thus improve the system performance. 


\section{REFERENCES}

1. AlMeidA, A. A. F.; FERnANDES, L. R.; AZEVEDO, E. H. M.; PINHEIRO, R. S. A.; LOPES, L. W. Características Vocais e de Personalidade de Pacientes com Imobilidade de Prega Vocal. CoDAS 2015; 27(2):178-95.

2. ALVES, R. L.; SOARES, A. M. J.; OLIVEIRA, G. (2014). Utilização de Estímulos Vísuo-Táteis para o Desenvolvimento da Oralidade e Educação de Surdos. CINTEDI - Congresso Internacional de Educação e Inclusão, Campina Grande - PB: 2014.

3. ANDRADE, L. D. F.; LACERDA JUNIOR, F. C. X.; MEDEIROS, H. A.; GONÇALVES, R. L. Almportância da Saúde Vocal em Diferentes Categorias Profissionais: uma revisão integrative. Revista da Universidade Vale do Rio Verde. Três Corações, v. 13, n. 1, p. 432 441, 2015

4. ANDREIS-WITKOSKI, S. FILIETAZ, M. R. Educação de Surdos em Debate. Editora da Universidade Tecnológica Federal do Paraná. UTFPR, 2014.

5. ARAÚJO, A. M. L. Jogos Computacionais Fonoarticulatórios Para Crianças com Deficiência Auditiva. Tese de Doutoramento - UNICAMP, 2000.

6. BARBACENA, I. L., Melhoria da Qualidade da Voz de Deficientes auditivos Utilizando-se Correção da Frequência Fundamental. Tese de Doutoramento - UFCG, 2010.

7. BARROS, A. T., Estimulação Tátil aplicada ao ensino da fala. Tese de Doutorado, Universidade Federal de Campina Grande. Campina Grande: 2004.

8. BEHLAU, M. FonoTools: Software para Disturbios da Comunicação. (Website). Paraná, Brasil: CTS Informática, 2012. Disponível em: http://www.ctsinformatica.com.br/\#fono Tools.html. Acesso em 23 Fev. 2016.

9. BEVILACQUA, M. C.; MARTINEZ, M. A. M.; BALEN, S. A.; PUPO, A, C.; REIS, A. C. M. B.; FROTA, S. (orgs.). Tratado de Audiologia. 880 p. São Paulo: Editora Santos, 2011.

10. BOERSMA, P.; WEENINK, D. Praat: doing phonetics by computer. Amsterdam: Institute of Phonetic Sciences, University of Amsterdam; 2012. Disponível em http://www.fon.hum. uva.n1/praat/. Acesso em 23 Fev. 2016.

11. CHRISTMANN, M. K.; BRANCALIONI, A. R.; FREITAS, C. R.; VARGAS, D. Z.; SOARES, M. K; MEZZOMO, C. L.; MOTA, H. B. Uso do Programa MDVP em Diferentes Contextos: Revisão de Literatura. Rev. CEFAC. 2015 Jul-Ago; 17(4):1341-1349.

12. CIELO, C. A.; RIBEIRO, V. V.; BASTILHA, G. R.; SCHILLING, N. O. Qualidade de vida em voz, avaliação perceptivoauditivo e análise acústica da voz de professores com queixas vocais. Audiol Commun Res. 2015;20(2):130-40.

13. COELHO, A. C. C.; BEVILACQUA, M. C.; OLIVEIRA, G.; BEHLAU, N.; Relação entre voz e Percepção de Fala em Crianças com Implante Coclear. Pró-Fono Revista de Atualização Científica. 2009 jan-mar; 21(1):7-12.

14. COSTA, S. C.; COREIA, S.; FALCÃO, H.; ALMEIDA, N.; ASSIS, F. Uso da Entropia na Discriminação de Vozes Patológicas. In: II Congresso de Inovação da Rede Norte e Nordeste de Educação Tecnológica, João Pessoa, PB, 2007.

15. CUNHA, J. C., Investigação em Estimulação Tátil por Jatos de CO2 Aplicada à Comunicação Alternativa. Tese de Doutorado. Universidade Tecnológica Federal do Paraná. Curitiba: 2012. 
16. EBERHARDT, S. P., BERNSTEIN, L. E., DEMOREST, M. E. \& GOLDSTEIN JR, M. H. Speechreading Sentences with Single-channel Vibrotactile Presentation of Voice Fundamental Frequency. Journal of Acoustical Society of America, vol 88, 3, setembro, 1990.

17. GATTO, C. I.; TOCHETTO, T.M.; Deficiência Auditiva Infantil: Implicações e Soluções. Revista CEFAC, vol. 9, num. 1, janeiro-março, 2007, pp. 110-115. Instituto Cefac, São Paulo, Brasil. Disponível em: Disponível em: http://www.redalyc.org/articulo.oa?id= 169313369014 Acesso em: 26, Out., 2015.

18. KING, A. J.; CALVERT, G. A. Multisensory integration: perceptual grouping by eye and ear. Current Biology, v. 11, n. 8, p. 322-325, 2001.

19. KREMER, R. L. A eficiência do disfarce na voz: uma análise da frequência fundamental. Anais do XXI Seminário do Centro de Estudos Linguísticos do Paraná. Paranaguá, 2014

20. LIMA, C.M.G.S., ALVES, R.L., FREIRE, R. C.S,; Correction of the Fundamental Voice Frequency Using Tactile and Visual Feedback, Proceedings of the 17th International ACM SIGACCESS Conference on Computers \& Accessibility - Assets 2015.

21. LUCCHESI, F. D. M.; ALMEIDA-VERDU; BUfFA, M. J. M. B.; BEVILACQUA, M. C. Análise dos passos de um Ensino Programado de Leitura e Escrita a Crianças com Deficiência auditiva e Implante Coclear. Acta Comportamentalia: Revista Latina de Análises de Comportamiento: Revista Latina de Análises de Comportamiento, vol. 23, num. 2, 2015, pp. 137 - 151. ISSN: 0188-8145. Disponível em: http://www.redalyc.org/articulo.oa? id=274538523004. Acesso em 23 Fev. 2016.

22. LUCCHESI, F. D. M.; ALMEIDA-VERDU; BUFFA, M. J. M. B.; BEVILACQUA, M. C. Análise dos passos de um Ensino Programado de Leitura e Escrita a Crianças com Deficiência auditiva e Implante Coclear. Acta Comportamentalia: Revista Latina de Análises de Comportamiento: Revista Latina de Análises de Comportamiento, vol. 23, num. 2, 2015, pp. 137 - 151. ISSN: 0188-8145. Disponível em: http://www.redalyc.org/articulo.oa?id=274538523004. Acesso em 23 Fev. 2016.

23. MARTINS, P. C.; COUTO, T.E.; GAMA, A. C. C. Avaliação perceptive-auditiva d grau de desvio vocal: correlação entre escala visual analogical e escala numérica. Escalas de avaliação da voz. CoDAS 2015; 27(3):279-84.

24. MARTINS, P. C.; COUTO, T.E.; GAMA, A. C. C. Avaliação perceptive-auditiva d grau de desvio vocal: correlação entre escala visual analogical e escala numérica. Escalas de avaliação da voz. CoDAS 2015;27(3):279-84.

25. MENDES, A. P; FERREIRA, L. J. L.; CASTRO, E. sofwares e hardwares de Análise acústica da voz e da fala. Distúrb Comun, São Paulo, 24(3): 421-430, dezembro, 2012

26. MENDONÇA, R.A.; SAMPAIO, T. M.M.; PROVENZANO, L. Medida do Tempo Máximo de Fonação de Professoras do Município de Niterói/RJ. Rev. CEFAC, São Paulo, 2012.

27. OLIVEIRA, P. S; PENNA, L. M.; LEMOS, A. M. A. Desenvolvimento da Linguagem e Deficiência Auditiva: Revisão de Literatura. Linguagem e deficiência auditiva. Rev. CEFAC. 2015 NovDez; 17(6):2044-2055.

28. OLIVEIRA, P. S; PENNA, L. M.; LEMOS, A. M. A. Desenvolvimento da Linguagem e Deficiência Auditiva: Revisão de Literatura. Linguagem e deficiência auditiva. Rev. CEFAC. 2015 NovDez; 17(6):2044-2055. 
29. PEREIRA, R. M. Análise Acústica e Perceptivo-Auditiva da voz de Crianças Usuárias de Implante Coclear Implantadas Antes e Após 4 Anos de Idade: Estudo Comparativo. Trabalho de Conclusão de Curso, Universidade Federal do Rio Grande do Norte. Natal - RN: 2013.

30. ROUAT, J., LIU, Y. C. And MORISSETTE D.,. A pitch determination and voiced/unvoiced decision algorithm for noisy speech. Speech Comm., 21:191-207, 1997

31. SADATOA, N., Okadaa, T., Kubotac, K. and Yonekurad, Y. Tactile discrimination activates the visual cortex of the recently blind naive to Braille: a functional magnetic resonance imaging study in humans, Neuroscience Letters Vol. 359 pp. 49-52, February, 2004.

32. SANTOS, M. K. Análise Acústica de Distúrbios Vocais Infantis Utilizando a Transformada Wavelet. Dissertação de Mestrado. Instituto Federal de Educação Ciência e Tecnologia da Paraíba. João Pessoa - PB, 2015.

33. SOUZA, L. B. R. Implante Coclear (re)habilitação da voz e da fala. Rio de Janeiro: Revinter, 2012.

34. SPERI, M. R. B.; A criança com Deficiência Auditiva: Da Suspeita ao Processo de Reabilitação Fonoaudiológica. Verba Volant. Volume 4 - Número 1 - janeiro-junho 2013 - ISSN 21784736. Disponível em: http://letras.ufpel.edu.br/verbavolant. Acesso em: 26, Out., 2015.

35. VALADEZ, V. et al., Voice Parameters and Videonasolaryngoscopy in children with Vocal Nodules: A Longitudinal Study, Before and After Voice Therapy. International Journal of Pediatric Otorhinolaryngology, v. 76. P. 1361-1365, 2012.

VIEIRA, V. J. D. Avaliação de distúrbios da voz por meio de análise de quantificação de ocorrência. Master's thesis, Instituto Federal de Educação Ciência e Tecnologia da Paraíba, Curso de Pós-Graduação em Engenharia Elétrica, João Pessoa, 2014. 